\title{
PERJUMPAAN TRANSFORMATIF YESUS DENGAN PEREMPUAN
}

\author{
Raulina Siagian \\ STT HKBP Pematangsiantar \\ raulinasgn@gmail.com
}

\begin{abstract}
Abstrak
Sebagai makhluk sosial, setiap orang pasti dan akan selalu mengalami perjumpaan dengan sesamanya. Manusia akan menemukan banyak kesempatan untuk mengalami perjumpaan dengan orang lain. Namun sebagian orang bisa mengalami perjumpaan yang berulang di kurun waktu yang lama dengan orang-orang tertentu, namun perjumpaan tersebut tidak memberi dampak yang signifikan bagi hidupnya. Artinya perjumpaan itu hanya sebatas rutinitas tanpa makna. Sementara itu, bagi yang lain, perjumpaannya dengan orang lain, meski dalam waktu yang relatif singkat, ternyata dapat memberi makna yang dalam baginya. Perjumpaan itu bahkan dapat memberi pengaruh besar bagi dirinya. Perjumpaan itu dapat mentransformasi dirinya, dapat menimbulkan perubahan paradigm berpikir, perubahan pemahaman, perubahan perasaan bahkan perubahan sikap hidup. Melalui perjumpaan tersebut ada nilai-nilai tertentu yang saling dibagikan dan memberi pengaruh positif bagi kehidupan antarpribadi yang saling berjumpa tersebut.

Perjumpaan transformatif itu sudah dialami para perempuan bersama dengan Yesus. Dalam perjumpaan-Nya dengan para perempuan Yesus sudah menghadirkan perubahan besar di tengah-tengah kemarginalan yang dialami perempuan. Yesus menghargai perempuan dan menempatkannya setara dengan laki-laki. Yesus membuka ruang bagi perempuan untuk berperan aktif di tengah-tengah misi yang dikerjakan-Nya dan yang selanjutnya dikerjakan oleh para murid-Nya.

Kiranya perjumpaan transformatif itu dapat menjadi dasar berpijak bagi para perempuan di masa kini untuk melanjutkan langkah dan perjuangan demi kehidupan yang lebih baik. Tantangan dan kesulitan tidak menjadi alasan untuk berhenti melainkan menjadi motivasi untuk semakin kreatif mencari dan mencipta peluang-peluang yang baik untuk berkembang serta semakin dinamis menghadapi berbagai tantangan yang muncul di tengah-tengah kehidupan bersama dengan orang lain.
\end{abstract}

Kata Kunci: Perjumpaan, transformatif, perempuan

\section{A. Pendahuluan}

Ketika tema "Keadilan Gender" diangkat ke permukaan maka sering menerima respons yang beragam. Sebagian orang berpikir bahwa itu merupakan tema yang sudah usang dan tidak relevan lagi dibicarakan, sebab perjuangan bagi keadilan gender sudah sampai pada titik puncak. Banyak perempuan sudah menikmati hasil dari perjuangan itu. Perempuan sudah tampil di mana-mana dan menempati posisi yang bergengsi di mana dia meniti karir. Sehingga tuntutan keadilan gender dirasa berlebihan dan tak perlu lagi. Namun bagi 
sebagian orang, tema ini tetap relevan untuk diperbincangkan, karena perjuangan bagi keadilan gender belum final. Betul banyak perempuan sudah mengalami perubahan dan perkembangan yang signifikan, namun masih banyak perempuan yang belum terbebas dari tirani ketidakadilan gender. Masih banyak perempuan yang mengalami penindasan dan diskriminasi, diposisikan sebagai subordinan dan dibatasi dalam banyak hal. Hasil perjuangan bagi keadilan gender belum maksimal dan belum final. Itu sebabnya tema "Keadilan Gender" perlu tetap diangkat ke permukaan, didiskusikan, diperbincangkan, disharingkan, sehingga keadilan gender benar-benar dialami banyak orang, secara khusus dialami para perempuan.

Melalui pengamatan dan sharing dengan beberapa perempuan maka perlu diketahui bahwa masih banyak perempuan yang masih konsisten dan bersemangat memperjuangkan cita-cita keadilan gender, meskipun ada juga yang tertatih tatih melakukannya, namun sebagian sudah hopeless karena sering menerima respons yang kurang positif, akhirnya mereka menyerah bahkan mundur hingga ke titik nol dan menerima keadaannya sebagai "nasib dan kodrat." Oleh karena itu, tulisan ini kiranya dapat memotivasi banyak pihak, secara khusus para perempuan, untuk tetap berjuang menciptakan perubahan sehingga banyak pihak dapat menikmati hidup yang lebih baik dan berkeadilan. Penggalian beberapa buku mengenai kisah para perempuan di zaman kuno dan secara khusus kisah perempuan di zaman Yesus kiranya dapat memberi pijakan yang kokoh bagi para perempuan untuk bangkit dan berjuang menghadapi

1 Syaifullah Mangantjo, "Kata Deddy, Di Belakang Pria Hebat Ada Wanita Tepat," dalam berbagai tantangan dan meraih cita-cita dan harapan akan hidup yang lebih baik.

\section{B. Pembahasan}

1. Pengalaman Perempuan di Zaman Kuno

Perempuan merupakan figur yang memiliki peran dan kedudukan penting bahkan sentral dalam kehidupan. Keberadaan, peran dan kedudukan perempuan merupakan fakta yang tidak terbantahkan. Itulah sebabnya ada slogan yang mengatakan "Di belakang pria hebat ada wanita tepat." Karena itu, jika ada laki-laki yang berhasil maka perlu mencari tahu siapa perempuan (ibu/istri/putri) yang bersama dengan dia dan yang mendukung dia. Itu sebabnya, tidak berlebihan untuk mengatakan bahwa keberhasilan seorang laki-laki sering sekali ditentukan oleh perempuan yang bersama dengan dirinya.

Tentu ada banyak hal telah dilakukan perempuan untuk mendukung keberhasilannya dan keberhasilan orangorang yang bersama dirinya. Tentu ada banyak peran penting perempuan bagi kehidupan. Namun secara paradoks, peran penting perempuan sering dikaburkan, sehingga segala sesuatu yang dipikirkan, dikatakan dan dilakukan oleh kaum perempuan sering dianggap tidak penting. Banyak pihak memang mengakui peran penting perempuan, tetapi masih ada juga segelintir orang tertentu yang berusaha mengaburkan dan menyangkal peran tersebut. Ada pihakpihak tertentu yang menyangkal bahwa keberadaan perempuan sangat menentukan kehidupan keluarga, masyarakat, dan negara. Pengaburan peran penting perempuan sebagaimana disebutkan di atas dapat dibuktikan melalui kenyataan bahwa sebagian 
perempuan masih mengalami ketidakadilan gender, dilecehkan, diremehkan, dinomorduakan, dibatasi dalam banyak hal dan sering tidak diperhitungkan dalam posisi sebagai pengambil keputusan (decision maker). Karena dianggap tidak mampu, perempuan sering diposisikan hanya sebagai pelaksana keputusan yang sudah ditetapkan oleh laki-laki. Perempuan seolah-olah hanya layak bermain di belakang layar karena panggung itu adalah milik laki-laki.

Kondisi ini sudah berlangsung cukup lama. Narasi Alkitab dan informasi di seputar penulisan teks-teks Alkitab memberi banyak keterangan tentang pengalaman perempuan di masa lampau. Karena konteks keyahudian dan keyunanian memberi pengaruh kuat dalam proses penulisan teks-teks Alkitab maka perlu melihat sekilas bagaimana posisi dan peran perempuan di masyarakat Yahudi dan Yunani.

Menurut Ben Witherington III, perempuan Yahudi memiliki hak yang sangat terbatas, termasuk hak atas dirinya sendiri. Perempuan, kata Witherington III, tidak bisa menentukan dan memutuskan perjalanan hidupnya sebab yang menentukan dan memutuskan adalah laki-laki, yaitu ayahnya sebelum dia menikah, kemudian suaminya setelah dia menikah, serta putranya setelah ia menjadi janda atau sudah lanjut usia. Konsekuensinya adalah bahwa di sepanjang hidupnya, perempuan selalu dituntut untuk taat, tunduk, hormat dan setia kepada laki-laki. Tanpa ketundukan itu, perempuan akan dipandang rendah dan negatif. Penghargaan kepada perempuan selalu dihubungkan dengan

\footnotetext{
${ }^{2}$ Ben Witherington III, Women in the Ministry of Jesus (Cambridge: Cambridge University, 1984), 2-3,5.

3 Paul K. Jewett, MAN: As Male and Female (Grand Rapids, Michigan: WB.Eerdmans
}

konsep kesetiaan kepada laki-laki (ayah dan suami) dan tanggung jawab kepada tugas-tugas domestik, demi pelayanan kepada suami dan anak-anak. Perempuan diharuskan bekerja keras untuk mempersiapkan segala kebutuhan di dalam rumah tangga. Jika keperluan dalam rumah tangga (misalnya pakaian dan makanan yang layak) tidak terpenuhi dan jika anak-anak memiliki moral yang tidak terpuji maka perempuanlah yang pasti dipersalahkan. ${ }^{2}$

Pembatasan yang diberikan kepada perempuan bukan hanya di dalam ranah domestik, tetapi bahkan diberlakukan di dalam ranah publik. Perempuan memiliki kesempatan yang terbatas untuk beraktivitas di luar rumah, bahkan perempuan tidak diizinkan untuk bertemu dan berbincang-bincang dengan laki-laki yang bukan kerabatnya. Di samping itu, perempuan juga dibatasi dalam ibadah. Beberapa ahli, di antaranya Paul K. Jewett dan Leonard Swidler, memberi informasi bahwa perempuan Yahudi tidak diizinkan mempelajari Torah. Larangan itu didasarkan pada pandangan negatif para rabbi Yahudi kepada perempuan, misalnya rabbi Eliezer yang menyatakan bahwa lebih baik membakar kata-kata Torah daripada mempercayakannya kepada perempuan. Perempuan Yahudi harus berdiam diri di dalam ibadah, sehingga dibatasi di dalam berdoa dan dibatasi dalam mengajar anak-anaknya mengenai Torah. ${ }^{3}$

Namun berbeda dengan Jewett dan Swidler maka Witherington III menyatakan bahwa di tengah-tengah pembatasan yang dialami perempuan maka perempuan bukannya tanpa peran sama sekali. Untuk itu Witherington III

Publishing Company, 1975), 91. Leonard Swidler, "Jesus was a Feminist," dalam Border Regions of Faith: An Anthology of Religion and Social Change, ed. Kenneth Aman (Maryknoll: Orbis Books, 1987), 30-31. 
mengatakan bahwa latihan bagi seorang laki-laki Yahudi untuk dapat berpartisipasi di Sinagoge dan dalam pelayanan di Bait Suci (sebagai pemimpin, guru, imam, dan lain-lain) tentunya dimulai di rumah. Di samping itu perlu diketahui bahwa rumah sering dipahami sebagai ranah perempuan. Dengan demikian maka sangat terbuka peluang bagi ibu (tentunya bersama ayah) untuk turut serta mengajar dan mempersiapkan anak-anaknya sehingga mereka kemudian dapat berpartisipasi dalam Sinagoge. Perempuan dimungkinkan hadir sebagai guru dalam kasus yang terbatas, yaitu memberi beberapa perintah dasar tentang agama. Oleh karena itu sangat mungkin perempuan juga mendapat pengajaran tentang Torah sehingga kemudian dapat mengajarkan Torah, meski mungkin tidak dalam bentuk pengajaran formal. ${ }^{4}$ Ross $\mathrm{S}$. Kraemer juga menyebutkan bahwa prasasti Yahudi dari Asia Minor telah memberi bukti mengenai peran perempuan di ranah publik. Bahkan perempuan juga dapat berpartisipasi dalam Sinagoge, termasuk sebagai pemimpin Sinagoge. Meski tidak merupakan gambaran umum dan meskipun terdapat variasi di masingmasing Sinagoge, namun terdapat peluang bagi perempuan untuk berpartisipasi dalam aspek-aspek ritual dan pelayanan ibadah serta dalam aspek edukatif. Kedua orang tua sama-sama bertanggung jawab dalam mendidik anak. Peran ibu tidak hanya melahirkan, tetapi juga sebagai pengasuh dan pendidik anak. Hal ini jelas melalui nasihat yang diberikan kepada anak, di mana ayah dan ibu disebutkan di dalamnya. "Hai anakku, dengarkanlah didikan ayahmu dan jangan menyianyiakan ajaran ibumu." (Ams.

\footnotetext{
${ }^{4}$ Witherington III, Women, 6-9.

5 Ross S. Kraemer, "Hellenistic Jewish Women: The Epigraphical Evidence," dalam Society of
}

1:8; 6:20). Di samping itu masih terdapat berbagai kisah dalam Alkitab yang memaparkan peran penting perempuan, misalnya cerita tentang Rut, Ester, dan Yudit, Maria Ibu Yesus, Maria Magdalena, dan lain-lain. ${ }^{5}$

Dengan demikian maka dapat dipahami bahwa meskipun secara umum perempuan Yahudi mengalami pembatasan di banyak aspek kehidupannya, namun mereka masih tetap berusaha melakukan peran penting di tengah-tengah keluarga dan masyarakat. Pembatasan yang mereka alami tidak membuat mereka berhenti tetapi tetap berusaha melihat peluang, sekecil apa pun itu, untuk tetap melakukan sesuatu yang berguna bagi kehidupan. Memang tidak banyak, tetapi beberapa catatan Alkitab (PL dan PB) memberi gambaran bahwa perempuan Yahudi bukannya tanpa peran sama sekali. Hadirnya beberapa nama perempuan dalam catatan Alkitab dapat memberi sinyal mengenai pentingnya peran para perempuan tersebut di tengahtengah masyarakat saat itu. Perlu disadari bahwa tidak mudah untuk menghadirkan perempuan sebagai figur penting di tengah-tengah masyarakat Yahudi yang patriarkhal, jikalau mereka tidak punya peran yang penting dan sangat menentukan di tengah-tengah masyarakat.

Gambaran yang tidak jauh berbeda juga ditemukan dalam masyarakat Yunani, yang secara umum juga lebih menghargai laki-laki daripada perempuan. Pada umumnya perempuan dibatasi dan hanya dalam jumlah kecil perempuan yang dimungkinkan memiliki kuasa dan dapat membuat keputusan dalam hidupnya, yaitu perempuan aristokrat dan perempuan yang kaya.

Biblical Literature, ed. Kent Harold Richards (Atlanta, Georgia: Scholars Press, 1986), 193195. 
Perempuan pada umumnya tidak mendapat tempat dalam dunia intelektual. Fokus utama masyarakat Yunani adalah mengupayakan pendidikan putranya dan menjaga keperawanan putrinya. Anak laki-laki pada umur 6 atau 14 tahun sudah menjalani pendidikan dan hanya sedikit petunjuk bahwa anak perempuan menerima pendidikan. Kalau pun perempuan mendapat pendidikan, maka proses itu adalah untuk belajar membaca dan menulis. Proses pendidikan itu dilakukan di rumah oleh ibu mereka. Biasanya pelajaran itu berhubungan dengan tugas domestik, misalnya: memasak, mencuci, dan lain-lain. Hal itu didukung oleh konsep berpikir orang Yunani kuno, bahwa perempuan bertanggung jawab mengajar anak untuk berjalan tetapi laki-laki bertanggung jawab mengajar untuk berpikir. Oleh karena itu ketika perempuan meraih kesuksesan dalam diskusi filsafat dan ilmu pengetahuan, maka hal itu pun tidak dihargai. Ketika para perempuan di zaman Yunani Kuno dapat memberikan kontribusi berharga di bidang ilmu pengetahuan maka kontribusi atau ilmu itu tidak akan diakui dan diterima, kecuali kalau penemuan atau ilmu itu dilekatkan pada nama laki-laki dalam keluarganya. Jika ilmunya tersebut dinyatakan atas nama perempuan itu maka ilmu itu tidak akan diakui dan diterima. Kisah itu sudah dialami oleh Hypatia. Dia memiliki reputasi yang baik sebagai filsuf dan ahli Matematika, namun karena wewenang yang terbatas maka dia menuliskan pengetahuan dan ilmunya tersebut bagi (atas nama) ayahnya, Theon, yang juga ahli Matematika. ${ }^{6}$

\footnotetext{
6 Sue Blundell, Women in Ancient Greece (Massachusetts: Harvard University Press, 1995), 114-133. Grainne McLaughlin, "The Logistics of Gender from Classical Philosophy," dalam Women's Influence on
}

Oleh karena itu maka dapat dikatakan bahwa perempuan Yunani juga memiliki status subordinan. Meskipun perempuan telah melakukan hal-hal penting di tengah-tengah keluarga dan masyarakat, tetapi peran tersebut sering diabaikan dan dikaburkan. Sebagai contoh, di Athena pada zaman klasik perempuan tidak diikutsertakan secara langsung dalam aktivitas politik. Perempuan tidak mempunyai hak politik. Bahkan ketika hukum yang menjelaskan asal usul orang Athena diperkenalkan, sesungguhnya perempuan melakukan peran yang sangat menentukan, yaitu sebagai "alat" dalam penyampaian hak warga negara, namun justru di saat itu pun perempuan tetap tidak memiliki hak politik. Sesungguhnya dalam proses itu perempuan melakukan peran penting dan itu merupakan hak istimewa bagi perempuan, namun justru dalam kesempatan itu pun perempuan tetap marginal. Mereka dikeluarkan dari lembaga negara dan tidak dipertimbangkan sebagai warga negara. Sebaliknya laki-laki memiliki hak politik yang penuh sebagai warga negara. ${ }^{7}$

Berbagai bentuk pembatasan dan ketidakadilan juga dialami oleh perempuan Yunani, namun hal itu tidak serta merta menghapus semua kreativitas mereka. Mereka masih mampu terlibat dalam urusan publik, meski dalam ruang yang sangat terbatas dan sering tidak mendapat apresiasi yang positif. Meski dalam banyak hal para perempuan Athena menjalani hidup yang memprihatinkan, namun tidak di sepanjang hidupnya perempuan memiliki status rendah. Berdasarkan bukti dari beberapa prasasti maka diperoleh

Classical Civilization, ed. Fiona Mchardy and Eirean Marshall (London \& New York: Routledge Taylor \& Francis Group, 2004), 16, 23.

${ }^{7}$ Blundell, Women, 114-133. 
informasi bahwa beberapa perempuan dari kelas saudagar dapat memiliki serta menjalankan bisnis dan mereka menjadi terpandang. Pendeta perempuan juga sangat dihargai. Meski beberapa pendeta kepala di dalam Eleusinian Mysteries adalah laki-laki, tetapi perempuan tetap memimpin ritus perayaan The Great Goddess. Bahkan di zaman Romawi di abad ke-3 M pendeta kepala dari The Great Goddess diturunkan dari seorang ibu kepada putrinya. Spiritualitas istimewa menjadi salah satu alasan bagi kehadiran para pendeta perempuan menjadi pemimpin di dalam hidup keberagamaan masyarakat Yunani. ${ }^{8}$ Penjelasan Frost ini sejajar dengan teori Ross S. Kraemer yang mengatakan bahwa di masa lampau perempuan telah hadir sebagai pemimpin. ${ }^{9}$

Dalam segala bentuk pembatasan dan diskriminasi yang dialaminya, peran penting para perempuan di tengah-tengah masyarakat Yahudi dan masyarakat Yunani tetap tidak terbantahkan. Keberadaan para perempuan zaman kuno itu dapat menjadi pembelajaran berharga bagi banyak perempuan di sepanjang zaman. Mereka mengalami pembatasan di kurun waktu yang sangat lama, namun mereka tidak kehilangan semua kesempatan untuk berperan aktif di tengah-tengah kehidupan. Pelajaran berharga juga dapat diperoleh para perempuan di zaman modern ini melalui kehadiran dan pelayanan Yesus bagi banyak orang, secara khusus bagi para perempuan.

\section{Perjumpaan Transformatif Yesus dengan perempuan}

"Ketidakadilan dan diskriminasi" merupakan gambaran umum dari pengalaman perempuan di zaman kuno

8 Frank J.Frost, Greek Society (Toronto: D.C.Heath and Company, 1987), 94-95. (di tengah-tengah masyarakat Yahudi dan Yunani). Laporan Alkitab juga memperlihatkan nuansa penindasan yang dialami perempuan di tengah-tengah masyarakat pada zaman kuno tersebut. Perempuan mengalami pembatasan di banyak kesempatan hidupnya. Peran penting perempuan, yang seharusnya tidak dapat disangkal (karena secara langsung dan tidak langsung telah bersentuhan dengan banyak orang di sekitarnya) namun secara praxis sering dipandang sebelah mata. Hal itu terlihat dari kurangnya penghargaan dan kesempatan yang diberikan kepada perempuan. Bahkan ada pembatasan yang luar biasa kepada perempuan. Hal ini semakin didukung oleh nilai-nilai patriarkhal yang berkembang di tengahtengah masyarakat, yang akhirnya menyebabkan perempuan sering tidak mendapat tempat sebab panggung dunia seolah-olah adalah milik laki-laki. Banyak hal penting yang terjadi di tengah-tengah kehidupan, tetapi semua itu pada umumnya dipahami adalah oleh, demi dan untuk laki-laki. Laki-laki ditempatkan jauh lebih penting daripada perempuan. Kondisi itu akhirnya telah memarginalkan perempuan. Banyak perempuan semakin tidak berdaya, dianggap tidak berdaya dan tidak diberdayakan secara maksimal.

Demikianlah pengalaman banyak perempuan pada zaman itu. Namun kehadiran Yesus akhirnya memberi warna baru. Yesus membuka cakrawala baru di tengah-tengah dunia yang secara umum memarginalkan perempuan. Sebagai seorang Yahudi maka Yesus memahami konteks kehidupan masyarakat Yahudi. Namun melalui kehadiran-Nya Yesus membangun nilainilai baru terhadap maskulinitas dan

\footnotetext{
${ }^{9}$ Ross S. Kraemer, "Women in the Religions of the Greco-Roman World," Religious Studies Review 9, no. 2 (April 1983), 127.
} 
terhadap feminimitas dalam Yudaisme. Yesus melakukan banyak hal demi terciptanya komunitas yang sederajat. Yesus memberi berbagai kritik kepada orang-orang Farisi, ahli-ahli Taurat, dan khalayak ramai. Yesus mengkritisi banyak hal, di antaranya tentang hari sabat, tentang posisi laki-laki dan perempuan, masalah najis dan suci, dan lain-lain. Secara khusus Rosemary Radford Ruether mengatakan bahwa intisari dari pesan dan pengajaran Yesus adalah kritik yang radikal terhadap ideologi yang dianut masyarakat, yaitu ideolog patriarkhal. Semua kuasa dan dominasi dalam masyarakat juga dikritik dengan tegas. Itu sebabanya dalam pelayanan Yesus dinyatakan: "Yang pertama akan menjadi yang terakhir, yang miskin akan berkelimpahan dan dihormati, para pelacur dan pemungut cukai ikut mendapat bagian dalam Kerajaan Surga dan mereka lebih dihargai daripada Farisi dan ahli Taurat."10

Perjumpaan golongan marginal, termasuk perempuan, dengan Yesus telah melahirkan sebuah perubahan besar. Yesus hadir sebagai motivator dan pelaku perubahan. Berbagai pengajaran dan tindakan Yesus dapat dipahami sebagai proses pembebasan bagi perempuan. Perempuan dibebaskan dari berbagai stereotipe negatif, dibebaskan dari penindasan dan pembatasan yang telah membelenggu perempuan untuk waktu yang lama. Dengan mengkritisi makna hukum taurat maka perempuan dibebaskan dari berbagai tuntutan hukum taurat yang begitu membelenggu dan menekannya. Masih ada berbagai tindakan yang Yesus lakukan kepada perempuan dan itu memberi makna pembebasan bagi perempuan.

${ }^{10}$ Rosemary Radford Ruether, Sexism and GodTalk: Toward a Feminist Theology (Boston: Beacon Press, 1983), 30.
Pengajaran dan tindakan Yesus telah menjadi motivasi penting bagi keikutsertaan perempuan dalam gerakan Yesus, karena Yesus telah memperjuangkan kesetaraan. Ada banyak perempuan yang ikut serta dalam gerakan Yesus, yang menjadi pengikut Yesus dan tetap menjadi pengikut Yesus, bahkan di saat The Historical Jesus tidak lagi bersama mereka. Kitab Perjanjian Baru mencatat kisah perempuan yang terlibat dalam gerakan Yesus, bahkan dalam gerakan para rasul di zaman kekristenan mula-mula. Para perempuan telah ikut mendukung dan terlibat aktif dalam pelayanan Yesus (Luk. 8:1-3), perempuan telah dipilih menjadi agent rekonsiliasi di tengah-tengah hubungan yang sudah lama rusak di antara orang Yahudi dan Samaria (Yoh. 4:1-42), perempuan telah dipilih dan diutus untuk menjadi saksi pertama kebangkitan Yesus (Yoh. 20:11-18), dan lain-lain. Selanjutnya perempuan juga terlibat aktif dalam pekerjaan misi bersama para rasul. Itu sebabnya Paulus juga merasa perlu memberikan salam kepada beberapa perempuan yang terlibat langsung dalam usaha penginjilan (Rm. 16). Di samping itu masih banyak laporan di luar Alkitab yang memberi informasi mengenai peran penting perempuan dalam misi kekristenan mula-mula. Perempuan telah melakukan peran penting di tengahtengah komunitas yang baru itu. Perempuan berada di antara para murid dalam masa pelayanan Yesus. Perempuan juga hadir sebagai dermawan yang mendukung misi Kristen, bahkan menjadi pelindung yang mengundang komunitas Kristen di dalam rumah mereka (jemaat rumah).

Keberadaan jemaat rumah
memberi gambaran bahwa beberapa 
warga yang agak mampu telah bergabung dengan gerakan Kristen dan mereka telah menyediakan tempat serta dukungan finansial bagi komunitas Kristen. Di antara jemaat yang menjadi fasilitator bagi jemaat rumah, terdapat beberapa perempuan. Bahkan menurut laporan Kisah Para Rasul 17:4,12 dinyatakan bahwa banyak perempuan terkemuka akhirnya percaya pada Yesus dan bergabung dengan komunitas yang dibangun Paulus. Para perempuan kaya di abad pertama itu akhirnya menjadi terkenal karena mereka membuka tempat tinggal dan rumah mereka sebagai tempat berkumpul dan tempat beribadah. Partisipasi kaum perempuan di jemaat rumah itu tentunya luar biasa dalam mendukung perkembangan penginjilan yang dilakukan rasul Paulus. Itu sebabnya di antara 25 orang yang dikirimi salam secara pribadi oleh Paulus, ada 9 orang perempuan ( $\mathrm{Rm}$. 16). Kesembilan perempuan itu adalah Priskila, Maria, Yunias, Trifena, Trifosa, Persis, ibunya Rufus, Yulia dan saudara perempuan Nereus; disamping nama Febe yang juga disebutkan di dalam perikop tersebut. ${ }^{11}$

Ada sebuah perubahan besar yang terjadi melalui kehadiran Yesus. Banyak laporan Injil yang menjelaskan sikap, pengajaran dan tindakan Yesus yang menegaskan nilai-nilai kesetaraan. Dalam konteks patriarkhal yang begitu kuat dalam masyarakat Yahudi dan Yunani, secara radikal Yesus telah menyatakan keberpihakannya kepada kaum lemah, secara khusus kepada perempuan. Dalam berbagai perjumpaan dengan perempuan, Yesus menegaskan kesetaraan laki-laki dan perempuan. Laki-laki dan perempuan sama-sama berhak untuk mendapat belas kasihan
Tuhan dan mendapat bagian dalam Kerajaan Surga.

Secara khusus Sandra $M$. Schneiders mencatat beberapa hal penting dalam perjumpaan Yesus dengan para perempuan sebagaimana dituliskan dalam Injil Yohanes. (1) Semua perempuan dalam Injil Yohanes dihadirkan secara positif dan dalam hubungan yang intim dengan Yesus. Tidak ada laporan mengenai perempuan yang menentang inisiatif Yesus, yang gagal untuk percaya, yang meninggalkan dan menyangkal Yesus atau yang mencobai-Nya. Hal ini sangat kontras dengan gambaran Yohanes tentang lakilaki yang mengatakan dan melakukan hal yang sia-sia (13:37-38), munafik (12:46), tidak percaya (9:24-41), dan berbagai catatan negatif tentang laki-laki (2) Gambaran positif Yohanes tentang perempuan bukan pada satu dimensi saja dan bukan stereotipikal. Perempuan muncul sebagai karakter pribadi yang kontras dengan figur laki-laki. Siapa pun yang menulis Injil Yohanes, dia adalah orang yang kaya dengan nuansa pengalaman religius perempuan. Secara historis, pengetahuan ini dapat merupakan hasil dari imajinasi aktif, tetapi lebih mungkin merupakan hasil pengalaman aktual mengenai perempuan yang memiliki peran dominan dalam komunitas Yohanes. (3) Perempuan dalam Injil Yohanes melakukan perannya tidak berdasarkan tradisi dan budaya patriarkhal yang secara umum membatasi mereka. Penghargaan terhadap peran penting yang mereka lakukan diberikan tanpa bergantung kepada laki-laki. Kecuali Maria ibu Yesus dan Maria Kleopas, para perempuan itu tidak dihadirkan sebagai istri atau ibu yang memiliki hubungan dengan laki-laki.

11 Elizabeth S. Fiorenza, Untuk Mengenang Perempuan Itu Terj. Stephen Suleeman (Jakarta: BPK-GM, 1995), 234-240. 
Tidak ada penjelasan mengenai relasi mereka dengan para laki-laki. Artinya mereka diterima dan dihargai bukan karena laki-laki. Mereka adalah perempuan merdeka yang diakui dalam menyaksikan Injil, dapat melakukan diskusi teologis, melayani, dan berperan dalam komunitas Yohanes. ${ }^{12}$

Dengan demikian maka dapat disimpulkan bahwa perempuan dalam Injil hampir seluruhnya digambarkan secara positif dan memiliki hubungan yang khusus dengan Yesus. Mereka memiliki pengalaman keagamaan yang bersifat pribadi dan kelihatannya berpartisipasi penuh dalam komunitas Yohanes.

\section{Penutup}

"Pengalaman adalah guru yang terbaik." Perkataan ini hendak mengajak banyak orang untuk melakukan evaluasi terhadap apa yang sudah terjadi, untuk belajar dari pengalaman hidupnya, untuk belajar dari peristiwa demi peristiwa yang terjadi dalam hidupnya. Setiap orang pasti punya pengalaman, baik yang menyedihkan maupun yang menggembirakan, dan pasti ada banyak pelajaran penting yang dapat diperoleh dari setiap pengalaman yang ada. Misalnya, dari keberhasilan kita bisa belajar tentang makna "ucapan syukur" dan melalui kegagalan kita boleh belajar mengenai makna sebuah kesabaran. Masih ada banyak hal lain yang dapat dipelajari dari pengalaman yang pernah terjadi dalam hidup kita.

Secara khusus pada kesempatan ini, pengalaman perempuan di masa lalu dapat menjadi cermin bagi para perempuan di masa kini. Dari penjelasan di atas dapat dipahami bahwa untuk waktu yang lama, di berbagai lapisan

12 Sandra M. Schneiders, "Women in the Fourth Gospel and the Role of Women in the Contemporary Church," dalam The Gospel of masyarakat, perempuan, yang adalah bagian dari anggota masyarakat, telah mengalami berbagai bentuk ketidakadilan, di antaranya penindasan, pembatasan, diskriminasi, dan lain-lain. Meskipun perempuan sudah melakukan peran penting di tengah-tengah keluarga dan masyarakat, namun sering sekali peran dan karya perempuan tetap dianggap sebagai sesuatu yang tidak (kurang) penting. Perjumpaan dan kebersamaan yang dialami perempuan dengan keluarga dan dengan anggota masyarakat di mana dia hidup, sering kali tidak memberi pengaruh yang membangun bagi dirinya. Orang-orang yang tinggal dan hidup bersama dengannya seakan diam tak bergeming, tanpa upaya yang jelas dan maksimal dalam mengakhiri penderitaan dan ketidakadilan yang dialaminya, bahkan terkesan ada upaya pembiaran dan pelanggengan berbagai ketidakadilan yang dialami perempuan. Bertahuntahun, bahkan ratusan dan ribuan tahun perempuan sudah mengalaminya, namun seakan ketidakadilan itu tetap dilestarikan dan dipelihara. Itu sebabnya penderitaan itu tidak hanya dialami orang-orang yang belum mengenal Kristus Yesus, tetapi juga dialami oleh para perempuan di sekitar Yesus dan di sekitar para rasul, bahkan dialami oleh para perempuan di sekitar gereja di masa kini.

Pengalaman itu begitu nyata, betul-betul terjadi. Tetapi banyak orang yang telah bertemu dan hidup bersama dengan para perempuan itu, mereka seakan tidak peduli dan tidak turut merasakan bahwa itu juga deritanya. Umat Kristen perdana hingga umat Kristen masa kini berulang kali membicarakan kesatuan tubuh Kristus,

John as Literature: An Anthology of TwentiethCentury Perspectives, ed. Mark W.G. Stibbe (Leiden: E.J. Brill, 1993), 129-130. 
namun sudah seberapa dalam mereka memperdulikan pengalaman pahit para perempuan. Akibatnya, banyak perempuan telah menderita dan masih menderita. Akankah penderitaan perempuan masih berkelanjutan? Ini pertanyaan penting untuk merangsang pikiran, perasaan dan aksi nyata dari kita.

Para perempuan patut bersyukur, dalam perjumpaan yang tidak terlalu lama dengan The Historical Jesus banyak perempuan, sebagaimana telah dicatat dalam teks Perjanjian Baru, akhirnya bisa bernafas lega karena sudah mengalami pembebasan yang dilakukan Yesus. Belenggu itu sudah diputus. Yesus memberi ruang yang setara bagi laki-laki dan perempuan. Yesus menghargai perempuan dan memberi kesempatan baginya untuk turut ambil bagian dalam karya keselamatan yang dikerjakanNya di dunia ini. Yesus mempercayakan pelayanan misi kepada perempuan, serta banyak hal lainnya yang dikerjakanNya bagi banyak manusia, secara khusus bagi perempuan.

Perjumpaan Yesus dengan para perempuan, sebagaimana telah dicatat dalam Alkitab telah mentransformasi banyak perempuan, sehingga para perempuan itu mau bangkit dan berjuang. Tantangan dan kesulitan serta hambatan masih tetap dialami perempuan, dalam bentuk yang beragam, bahkan hingga saat ini, tetapi para perempuan yang sudah mengalami perjumpaan dengan Yesus tidak perlu takut dan gentar. Pengalaman para perempuan di dalam Alkitab memperlihatkan betapa para perempuan terlihat begitu dinamis menyikapi dan menghadapi tantangan yang ada, dengan terus dan terus berkarya di tengah-tengah kehidupan. Kesaksian Maria Magdalena diragukan oleh para murid, namun dia tidak berhenti bersaksi. Perempuan Samaria mendapat stereotipe negatif namun tidak menyurutkan langkahnya untuk memberitakan kepada saudara sekampungnya bahwa dia sudah bertemu Yesus. Meskipun ada respon negatif dari Yudas namun Maria tetap mengurapi kaki Yesus dengan hati yang tulus. Meskipun mendapat ujian berat melalui perkataan "anjing" namun perempuan Siro-Fenesia itu tidak berhenti untuk percaya dan berharap pada Yesus.

Akhirnya perlu ditegaskan bahwa perjumpaan para perempuan dengan Yesus sudah melahirkan perubahan besar. Perempuan bukan makhluk lemah, sebagaimana sering disebutkan padanya. Perempuan adalah orang yang tangguh dan dapat diandalkan serta kuat dalam mengemban banyak tanggung jawab yang dibebankan kepadanya. Bahkan ketika sebagian suami sepertinya sudah melepas tanggung jawabnya, maka para perempuan hadir memikul tanggung jawab itu sendiri dan menghantar anakanaknya ke masa depan yang lebih baik. Perempuan bukan orang bodoh yang siap untuk dibodoh-bodohi atau yang masa bodoh dengan situasi yang terjadi, tetapi dengan penuh hikmat banyak perempuan telah berhati-hati dan bijaksana dalam mengambil keputusan dan bertindak supaya apa yang dilakukannya tidak merusak dirinya dan orang lain. Perempuan bukan lagi makhluk yang emosional sebagaimana sering juga dicitrakan padanya, tetapi dia adalah pribadi yang responsif dan kreatif dalam menghadapi situasi yang terjadi dalam hidupnya. Dengan demikian maka tidak perlu diragukan serta tak perlu disangkal, perempuan adalah tokoh yang berperan penting bagi kehidupan, yang dapat menciptakan banyak perubahan positif bagi dirinya dan bagi dunia di mana dia hidup. Sehingga tidak perlu ada alasan untuk berhenti berjuang meraih cita-cita dan harapan akan kehidupan yang lebih baik, hidup yang setara dan berkeadilan, hidup yang memberi ruang dan 
kesempatan yang sama bagi setiap insan untuk berkarya mencipta banyak perubahan yang positif di tengah-tengah kehidupan.

Secara khusus kiranya perjumpaan transformatif yang sudah dialami para perempuan bersama The Historical Jesus dapat menjadi dasar berpijak bagi para perempuan di masa kini untuk mengevaluasi pengalaman hidupnya. Dalam perjumpaannya bersama dengan orang lain di tengahtengah keluarga dan masyarakat tentu ada banyak hal yang bisa dialami, dilihat, didengar, dipikirkan, baik hal positif maupun hal negatif. Semua itu dapat menjadi kesempatan yang baik untuk belajar banyak hal yang berguna dan bermanfaat demi terciptaknya perubahan positif dalam rangka membangun diri kita sendiri dan membangun orang-orang di sekitar kita. Berbagai bentuk pengalaman itu kiranya tidak menyurutkan langkah untuk maju melainkan semakin membuka ruang agar semakin kreatif mencari dan mencipta peluang-peluang untuk berkembang serta semakin dinamis menghadapi berbagai tantangan yang muncul di tengah-tengah kehidupan. Teruslah berjuang karena selalu ada harapan untuk menjalani hidup yang lebih baik.

\section{Referensi}

"Hellenistic Jewish Women: The Epigraphical Evidence," dalam Society of Biblical Literature, ed. Kent Harold Richards (Atlanta, Georgia: Scholars Press, 1986).

Blundell, Sue. Women in Ancient Greece (Massachusetts: Harvard University Press, 1995).

Fiorenza, Elizabeth S. Untuk Mengenang Perempuan Itu Terj. Stephen Suleeman (Jakarta: BPK-GM, 1995).

Frost, Frank J. Greek Society (Toronto: D.C.Heath and Company, 1987).
Jewett, Paul K. MAN: As Male and Female (Grand Rapids, Michigan: WB. Eerdmans Publishing Company, 1975).

Kraemer, Ross S. "Women in the Religions of the Greco-Roman World," Religious Studies Review 9, no. 2 (April 1983).

Mangantjo, Syaifullah. "Kata Deddy, Di Belakang Pria Hebat Ada Wanita Tepat," dalam http://syaifillahmangantjo.wordpre ss.com (diakses 24 Mei 2019).

McLaughlin, Grainne. "The Logistics of Gender from Classical Philosophy," dalam

Ruether, Rosemary Radford. Sexism and God-Talk: Toward a Feminist Theology (Boston: Beacon Press, 1983).

Schneiders, Sandra M. "Women in the Fourth Gospel and the Role of Women in the Contemporary Church," dalam The Gospel of John as Literature: An Anthology of TwentiethCentury Perspectives, ed. Mark W.G. Stibbe (Leiden: E.J. Brill, 1993).

Swidler, Leonard. "Jesus was a Feminist," dalam Border Regions of Faith: An Anthology of Religion and Social Change, ed. Kenneth Aman (Maryknoll: Orbis Books, 1987).

Witherington III, Ben. Women in the Ministry of Jesus (Cambridge: Cambridge University, 1984).

Women's Influence on Classical Civilization, ed. Fiona Mchardy and Eirean Marshall (London \& New York: Routledge Taylor \& Francis Group, 2004). 
